\title{
Development of pineapple and wine flavored fermented dairy product
}

\author{
Desenvolvimento de produto lácteo fermentado sabor abacaxi ao vinho \\ Elaboración de producto lácteo fermentado con sabor a piña
}

Received: 05/26/2021 | Reviewed: 05/31/2021 | Accept: 06/03/2021 | Published: 06/18/2021

Alessandro Campos Pereira
ORCID: https://orcid.org/0000-0002-7518-9093
E-mail: alessandro.acp@hotmail.com
Instituto Federal de Educação Ciência e Tecnologia do Triangulo Mineiro, Brazil
Fernanda Barbosa Borges Jardim
ORCID: https://orcid.org/0000-0002-4072-9889
E-mail: fernanda.jardim@iftm.edu.br
Marlene Jerônimo
Instituto Federal de Educação Ciência e Tecnologia To Triânulo Mineiro, Brazil
ORCID: https://orcid.org/0000-0001-7707-7258
Instituto Federal de Educação Ciência e Tecnologia do Triângulo Mineiro, Brazil
E-mail: marlene@iftm.edu.br

\begin{abstract}
The objective of this work was to take advantage of buttermilk and whey for the development of a pineapple and wine flavored fermented dairy product and to characterize the product in physicochemical, microbiological and sensorial terms. The experiment was carried out through four treatments with the following formulations: T0 (70\% UHT skim milk and 30\% whey), T1 (70\% buttermilk and 30\% whey), T2 (60\% buttermilk and 40\% whey), T3 (50\% buttermilk and 50\% whey). The average treatment values did not differ among themselves, at a 5\% level of significance, regarding $\mathrm{pH}$, acidity, viscosity and color. The protein and fat levels decreased with the increase of the amount of buttermilk in the treatment formulations. There was no significant difference, at a $5 \%$ level of significance, in the average acceptance values of the 57 judges for flavor, texture, aroma, color and overall impression, with values above 8.0 (9 point scale) for all attributes. In the purchase intention test, there also were no differences, with averages superior to 5.4 (7 point scale) for all formulations. All formulations had counts of total coliforms and E. Coli within the acceptable range, taking into consideration the legislation for fermented dairy beverages. Regarding the lactic acid bacteria, the counts were superior to $1.3 \times 10^{7} \mathrm{CFU} \mathrm{g}{ }^{-1}$ and also in accordance with the legislation. It was concluded that the use of buttermilk in the production of fermented dairy products is technologically feasible.
\end{abstract}

Keywords: Whey; Buttermilk; Sensorial analysis; Fermented dairy beverages; New dairy products.

\section{Resumo}

O objetivo deste trabalho foi aproveitar o leitelho e o soro de leite para o desenvolvimento de um produto lácteo fermentado sabor abacaxi ao vinho e caracterizar o produto em termos físico-químicos, microbiológicos e sensoriais. O experimento foi conduzido mediante quatro tratamentos com as seguintes formulações: T0 (70\% de leite UHT desnatado e 30\% de soro de leite), T1 (70\% de leitelho e 30\% de soro de leite), T2 (60\% de leitelho e $40 \%$ de soro de leite) e T3 ( $50 \%$ de leitelho e $50 \%$ de soro de leite). Os valores médios dos tratamentos não diferenciam entre si, ao nível de 5\% de significância, com relação ao $\mathrm{pH}$, acidez, viscosidade e cor. Os teores de proteína e gordura diminuíram com o aumento da quantidade de leitelho na formulação dos tratamentos. Não houve diferença significativa, ao nível de 5\% de significância, nos valores médios da aceitação de 57 julgadores para sabor, textura, aroma, cor e impressão global, com valores acima de 8,0 (escala de 9 pontos) para todos os atributos. No teste de intenção de compra, também não houve diferenças, com médias superiores a 5,4 (escala de 7 pontos) para todas as formulações. Todas as formulações apresentaram contagens de coliformes totais e E. coli dentro do aceitável, considerando a legislação para bebidas lácteas fermentadas. Com relação às bactérias láticas, as contagens foram superiores a $1,3 \times 10^{7} \mathrm{UFC} \mathrm{g}^{-1}$, também em conformidade com a legislação. Concluiu-se que o uso de leitelho na fabricação de produtos lácteos fermentados é viável tecnologicamente.

Palavras-chave: Soro de leite; Leitelho; Bebida láctea fermentada; Análise sensorial; Novos produtos lácteos.

\section{Resumen}

El objetivo de este trabajo fue utilizar suero de leche y suero para desarrollar un producto lácteo fermentado con sabor a piña y caracterizar el producto en términos físico-químicos, microbiológicos y sensoriales. El experimento se realizó mediante cuatro tratamientos con las siguientes formulaciones: T0 (70\% de leche desnatada UHT y $30 \%$ de suero de leche), T1 (70\% de suero de mantequilla y $30 \%$ de suero de leche), T2 (60\% de suero de mantequilla y $40 \%$ de suero de leche) y T3 (50\% de suero de mantequilla y $50 \%$ de suero de leche). Los valores promedio de los tratamientos no 
difirieron entre sí, al nivel del 5\% de significancia, en relación al pH, acidez, viscosidad y color. Los niveles de proteínas y grasas disminuyen con el aumento de la cantidad de leche en la cantidad de tratamientos. No hubo diferencia significativa, al nivel de significancia del 5\%, en los valores promedio de aceptación de 57 jueces para sabor, textura, aroma, color e impresión general, con valores por encima de 8.0 (escala de 9 puntos) para todos los atributos. En la prueba de intención de compra tampoco hubo diferencias, con promedios superiores a 5,4 (escala de 7 puntos) para todas las formulaciones. Todas las formulaciones alternativas de coliformes totales y coli dentro del rango aceptable, considerando la legislación para bebidas lácteas fermentadas. En relación a las bacterias del ácido láctico, los recuentos fueron superiores a 1,3 x 107 UFC g-1, también de acuerdo con la legislación. Se concluyó que el uso de suero de mantequilla en la fabricación de productos lácteos fermentados es tecnológicamente factible.

Palabras clave: Suero de leche; Suero de mantequilla; Bebida de leche fermentada; Análisis sensorial; Nuevos productos lácteos.

\section{Introduction}

Dairy activity in Brazil has evolved in recent years This has resulted in the growth of milk production, making the country one of the world's main producers. In 2020 alone, more than 25 billion liters of raw milk were processed in inspected establishments. This volume places the country in third place in worldwide milk production, behind the United States and India, respectively (Brazilian Institute of Geography and Statistics - IBGE, 2021; United Nations Food and Agriculture Organization FAO, 2021).

In addition to being consumed in natura, milk can be transformed into derivatives such as cheese, butter, yogurt, condensed milk, dulce de leche and powdered milk. Therefore, milk becomes one of the products most used by agribusinesses. In regards to dairy products, the most produced in Brazil are cheeses (1,333,330 tons produced in 2018), condensed milk (709,750 tons produced in 2018) and powdered milk (532,957 tons produced in 2018). Butter is also highly relevant in terms of production, with 116,647 tons produced in 2018 (Embrapa Gado de Leite, 2018; IBGE, 2021).

From the production of cheese and butter, unlike other derivatives, the by-products whey and buttermilk are generated. Whey is the liquid generated after cutting the curd, stirring the curd grains and pressing the mass. Buttermilk is the liquid generated after whipping the cream to form the butter.

Considering Brazilian cheese production in 2018, and that in the production of 1 kilo of cheese, an average of 9 liters of whey is generated (Alves et al., 2014), 12 billion liters of whey were generated that year. Considering the production of butter in the same year, and that from 1 kilo of butter an average of 0.5 liters of buttermilk is generated (Abreu \& Gajo, 2012), approximately 58 million liters of buttermilk were generated.

Even with this high amount of whey and buttermilk being generated, the use of these by-products is still low, mainly by small and medium-sized dairy factories, which tend to use these by-products for animal feed or simply dispose of them into the environment (Oliveira et al., 2012; Assumção \& Paula, 2013; Valente et al., 2015; Souza \& Hemkemeier, 2020). As a result, there is a need to use these by-products.

The use of buttermilk and whey for the development of new products provides increased profitability and greater competitiveness in the market. Industries transform these by-products with no commercial value into products with greater added value, thus providing a source of extra income (Alves et al., 2014; Souza \& Hemkemeier, 2020).

More and more consumers are looking for products that generate health benefits. Whey and buttermilk, in addition to being rich in nutrients, are by-products that have several functional properties, making them important raw materials in the generation of products that generate benefits for consumer health (Vanderghem et al., 2010; Assumção \& Paula, 2013; Alves et al., 2014). Consumers are also looking for new products and new sensations. Thus, the development of new flavors in food products is an attractive tool (Wille et al., 2004; Brazilian Service of Support to Micro and Small Companies - SEBRAE, 2018). This fact leads to the choice of exotic flavors, such as the pineapple and wine flavor for dairy products.

The objectives of this work are to use buttermilk and whey for the development of a pineapple and wine flavored 
fermented dairy product, to verify the product's acceptance and purchase intention and to characterize it in physicochemical and microbiological terms.

\section{Methodology}

The study was of a quantitative and experimental nature. The physicochemical, microbiological and sensory results of the dairy product formulations were obtained through laboratory analyses (Pereira et al., 2018).

\subsection{Materials}

The whey and buttermilk were supplied by the Unaí Agricultural Cooperative (CAPUL) located in Unaí, MG. The whey came from the production of Mozzarella cheese and the buttermilk was obtained through the production of butter produced with cream (standardized at $40 \%$ fat by adding water to the cream) and with biological maturation.

The whey and buttermilk were transferred to 10 liter High Density Polyethylene (HDPE) buckets with lids, previously sanitized with $0.2 \%$ sodium hypochlorite solution (10\% active chlorine content) and taken to a cold room to be cooled to a maximum temperature of $4^{\circ} \mathrm{C}$. They were then transported to the Agroindustry of the Juvêncio Martins Ferreira State School (Agricultural School), in Unaí, MG, where the fermented dairy product was manufactured. The buckets were kept in a cold chamber until it was time for the whey and buttermilk to be used.

\subsection{Formulation and production process of the fermented dairy product}

The experiment was carried out using four treatments (T0, T1, T2 and T3). The formulations were established after the pre-tests (Table 1).

Table 1. Formulations of fermented dairy product treatments with different proportions of whey and buttermilk.

\begin{tabular}{|c|c|c|c|c|}
\hline Treatments & T0 & T1 & $\mathbf{T} 2$ & T3 \\
\hline \multicolumn{5}{|l|}{ Base Mixture } \\
\hline UHT skim milk & $70 \%$ & - & - & - \\
\hline Whey & $30 \%$ & $30 \%$ & $40 \%$ & $50 \%$ \\
\hline Buttermilk & - & $70 \%$ & $60 \%$ & $50 \%$ \\
\hline \multicolumn{5}{|l|}{ Ingredients $^{1}$} \\
\hline Granulated sugar & $10 \%$ & $10 \%$ & $10 \%$ & $10 \%$ \\
\hline UHT cream (Piracanjuba $\left.{ }^{\circledR}\right)^{2}$ & Variable & Variable & Variable & Variable \\
\hline Skim milk powder $(\text { Itambé } ®)^{3}$ & Variable & Variable & Variable & Variable \\
\hline Pineapple and wine mix (Ricaeli®) & $10 \%$ & $10 \%$ & $10 \%$ & $10 \%$ \\
\hline Stabilizer and thickener (Rica Nata®) & $0.5 \%$ & $0.5 \%$ & $0.5 \%$ & $0.5 \%$ \\
\hline Lyophilized milk yeast (Rica Nata YR03®) ${ }^{4}$ & $0.4 \%$ & $0.4 \%$ & $0.4 \%$ & $0.4 \%$ \\
\hline Pineapple flavoring (Rica Nata $\left.{ }^{\circledR}\right)$ & $0.6 \%$ & $0.6 \%$ & $0.6 \%$ & $0.6 \%$ \\
\hline Artificial burgundy wine food coloring (Mix ${ }^{\circledR)}$ & $0.04 \%$ & $0.04 \%$ & $0.04 \%$ & $0.04 \%$ \\
\hline
\end{tabular}

Note: ${ }^{1}$ The percentage of each ingredient is based on the total volume of the base mixture. ${ }^{2}$ Amount calculated in order to standardize the base mixture to $10 \%$ NFDE. ${ }^{3}$ Amount calculated in order to standardize the base mixture to $1 \%$ fat. ${ }^{4}$ Composition: Streptococcus thermophilus and Lactobacillus delbrüeckii ssp. bulgaricus. Source: Authors (2021).

The production process of the treatments (Figure 1) was carried out by batch in a 50 liter fermenter (Solinox). First, the 
whey acidity analysis was performed and, when it was above $12^{\circ} \mathrm{D}$ (Dornic), it was corrected with powdered sodium bicarbonate (Junco ${ }^{\circledR}$ ) until it reached an acidity of $12^{\circ} \mathrm{D}$. The whey was then added to the fermenter where it was heated to $70^{\circ} \mathrm{C}$ (to inactivate the enzymes of the coagulant used to manufacture the cheese).

Figure 1. Flowchart for the production of the fermented dairy product treatments.

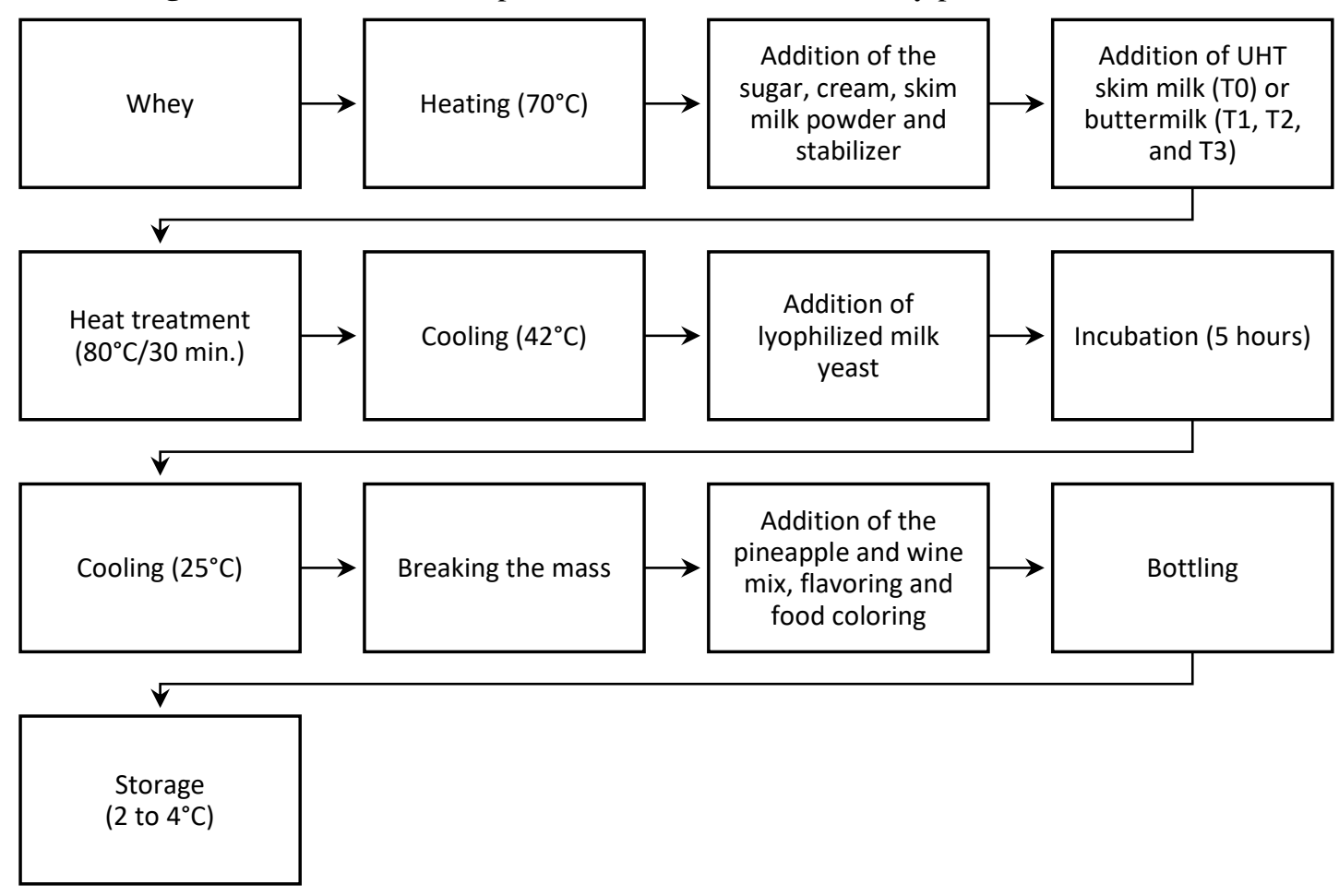

Source: Authors (2021).

Shortly afterwards, buttermilk with a maximum acidity of $12^{\circ} \mathrm{D}$ (for treatments $\mathrm{T} 1, \mathrm{~T} 2$ and T3) or UHT skim milk (for treatment T0) was added. The acidity was also corrected with sodium bicarbonate when necessary. Then, cream, granulated sugar, skim milk powder, thickener and stabilizer were added to the base mixture.

The obtained mixture was heat treated at $80^{\circ} \mathrm{C}$ for 30 minutes and then cooled until it reached $42^{\circ} \mathrm{C}$. Lyophilized milk yeast was added and kept at the same temperature for 5 hours. When the time came, the product was cooled to $25^{\circ} \mathrm{C}$ and the mass was broken with the aid of the fermenter's agitator. Along with the breaking of the mass, the pineapple and wine mix, the pineapple flavoring, and the food coloring were added. The stirring was maintained until a complete homogenization of the product was achieved (obtaining a uniform appearance). The pineapple and wine mix was previously pasteurized at $90^{\circ} \mathrm{C}$ for 3 minutes before being added to the pasteurized mixture (Rio de Janeiro Technology Network - RETEC/RJ, 2006).

The product was put into 1-liter HDPE bottles with lids, previously sanitized with $0.2 \%$ sodium hypochlorite solution (10\% active chlorine content) and kept cool in a cold chamber $\left(2\right.$ to $\left.4^{\circ} \mathrm{C}\right)$.

\subsection{Physicochemical and microbiological analyses}

The $\mathrm{pH}$, acidity, density, fat, TDE and NFDE analyses of the whey, buttermilk and UHT skim milk were carried out at the CAPUL Dairy Laboratory. The $\mathrm{pH}$, acidity and fat analyses of the cream were also carried out at the same place. However, the analyses of whey protein, buttermilk and skimmed UHT milk and the analyses of the treatments ( $\mathrm{pH}$, acidity, viscosity, color, protein, fat, lactic acid bacteria, total coliforms and E. coli) were carried out in the laboratories at the Federal Institute of Triângulo Mineiro's (IFTM) Uberaba campus. 
In order to perform the analyses at IFTM, the treatment samples were transported in an isothermal box with ice. The samples were kept in a refrigerator with a maximum temperature of $4^{\circ} \mathrm{C}$ until the time of the analyses.

For better characterization of the raw materials and treatments, physicochemical and microbiological analyses were performed on the UHT skim milk, whey, buttermilk, cream and on the treatments (Table 2).

The physicochemical analyses were carried out in triplicate and the microbiological analyses were carried out in duplicate.

Table 2. Physicochemical and microbiological analyses of the raw materials and the fermented dairy product treatments.

\begin{tabular}{cccccc}
\hline Analyses & UHT Skim & Whey & Buttermilk & Cream & Treatments \\
& Milk & & & & \\
\hline pH & $\mathrm{X}$ & $\mathrm{X}$ & $\mathrm{X}$ & $\mathrm{X}$ & $\mathrm{X}$ \\
Acidity & $\mathrm{X}$ & $\mathrm{X}$ & $\mathrm{X}$ & $\mathrm{X}$ & $\mathrm{X}$ \\
Density & $\mathrm{X}$ & $\mathrm{X}$ & $\mathrm{X}$ & - & - \\
Fat & $\mathrm{X}$ & $\mathrm{X}$ & $\mathrm{X}$ & $\mathrm{X}$ & $\mathrm{X}$ \\
TDE & $\mathrm{X}$ & $\mathrm{X}$ & $\mathrm{X}$ & - & - \\
NFDE & $\mathrm{X}$ & $\mathrm{X}$ & $\mathrm{X}$ & - & - \\
Protein & $\mathrm{X}$ & $\mathrm{X}$ & $\mathrm{X}$ & - & $\mathrm{X}$ \\
Viscosity & - & - & - & - & $\mathrm{X}$ \\
Color & - & - & - & - & $\mathrm{X}$ \\
Lactic Acid Bacteria & - & - & - & - & $\mathrm{X}$ \\
Total Coliforms & - & - & - & - & $\mathrm{X}$ \\
E. coli & - & - & - & - & $\mathrm{X}$ \\
\hline
\end{tabular}

Source: Authors (2021).

As the developed product is similar to a Fermented Dairy Beverage, the physicochemical and microbiological requirements for Fermented Dairy Beverages with the addition of food substances were used as a reference. These requirements are present in the Technical Regulation on Identity and Quality (RTIQ) for Dairy Beverages, Normative Instruction $n^{\circ} 16$ (Brazil, 2005).

The protein, $\mathrm{pH}$, titratable acidity, density, fat (cream, UHT milk, whey and buttermilk), total dry extract (TDE) and non-fat dry extract (NFDE) analyses were performed according to official methods established by Normative Instruction $\mathrm{n}^{\circ} 68$ (Brazil, 2006). The determination of fat from the fermented dairy product (treatments) was carried out as described by the Adolfo Lutz Institute (2008) using a butyrometer. Viscosity was determined using a viscometer (Brookfield brand, model DV-II+ Pro) and followed the procedures in the equipment manual (Brookfield, 2015). The color determination was carried out by means of a colorimeter (Konica Minolta brand, model Chroma Meter CR 400), using the CIELAB system, color space ( $\left.\mathrm{L}^{*} \mathrm{a} * \mathrm{~b}^{*}\right)$ and the Illuminant D65 (Konica Minolta, 2013).

For the microbiological analyses, $5 \mathrm{~g}$ of the sample were weighed and transferred to $225 \mathrm{~mL}$ of sterile peptone water, thus obtaining a $10^{-1}$ dilution. From this first dilution, $1 \mathrm{~mL}$ was pipetted and added to a tube containing $9 \mathrm{~mL}$ of peptone water, obtaining a $10^{-2}$ dilution. Thus, the remaining dilutions necessary for the analyzes were carried out. For total coliforms and $E$.

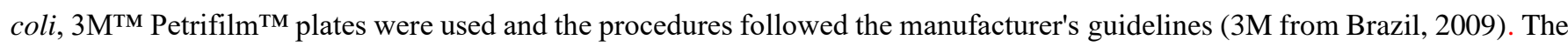
plates were incubated for 24 hours at $35^{\circ} \mathrm{C}$ (for total coliforms) and for E. coli, the incubation time was 48 hours. After the 
incubation period, the colonies were counted (with E. coli as blue colonies with gas and total coliforms as red and blue colonies with gas) and the results were expressed in Colony Forming Units (CFU g ${ }^{-1}$ ).

From the dilutions performed for the total coliform and E. coli analyses, the lactic bacteria analysis was carried out by pour plate with overlay, adding $1 \mathrm{~mL}$ of the dilution in a petri dish and then adding the MRS Agar (from Man Rogosa \& Sharpe). After solidification of the culture medium, another layer of the culture medium was added to ensure a more anaerobic environment. Soon after, the plate was incubated at $35^{\circ} \mathrm{C}$ for 48 hours (Silva et al., 2007). After the incubation period, the colonies were counted (red colonies with or without gas) and the results were expressed in Colony Forming Units (CFU g $\left.{ }^{-1}\right)$.

\subsection{Sensory Analysis}

The Sensory analysis was conducted at Unaí College of Health Sciences (FACISA) with teachers, students and technical-administrative staff from the same institution. The sensory analysis was submitted to and approved by the Federal University of Triângulo Mineiro's Research Ethics Committee (CEP) under protocol CAAE 15577619.0.0000.5154 and assessment number 3.461.652.

The sensory analysis was performed with the samples from the last repetition of the experiment and, after obtaining the results of the microbiological analyses. The judges were adult students, teachers and technical-administrative employees from FACISA, being selected only if they consumed dairy products in order to prevent the participation of those who are lactose intolerant or allergic to milk.

The sensory analysis was performed by 57 untrained judges. They assessed the purchase intention using a seven-point attitude scale and the degree of acceptance using the nine-point hedonic scale.

To perform the sensory analysis, the judges were in individual booths and about $30 \mathrm{~mL}$ of each formulation (with a temperature of 2 to $4^{\circ} \mathrm{C}$ ) was served in disposable $50 \mathrm{~mL}$ cups encoded with random three-digit numbers. Mineral water was served to eliminate the residual taste of each sample (Bento, Andrade \& Silva, 2013). All samples were presented in a monadic manner.

\subsection{Statistical Analysis}

The experiment was carried out considering four treatments and four repetitions for each treatment.

A completely randomized design (CRD) was used for the physicochemical analyses and a randomized block design (RBD) was used for the sensory analysis. The homogeneity and normality of the data were assessed by the Shapiro-Wilk and Bartlett tests, respectively, at 5\% significance. For the data from the microbiological analyses, geometric mean was applied.

The data from the physicochemical analyses were analyzed by the analysis of variance (ANOVA) and the averages were analyzed by the Scott-Knott test at 5\% significance. The Friedman test at 5\% significance was used for the statistical analysis of the judges' acceptance regarding taste, texture, aroma, color and overall impression.

The statistical software R 3.4.0 was adopted for the statistical analysis.

\section{Results and Discussion}

\subsection{Physicochemical Analyses}

The average results of the physicochemical analyses carried out on the raw materials are shown in Table 3. 
Table 3. Average results of the physicochemical analyses of the raw materials used in the elaboration of the fermented dairy product treatments.

\begin{tabular}{ccccc}
\hline Parameters & UHT Skim Milk & Whey & Buttermilk & UHT Cream \\
\hline $\mathrm{pH}$ & 6.69 & 6.41 & 6.72 & 6.74 \\
Acidity $\left({ }^{\circ} \mathrm{D}\right)$ & 18 & 13 & 19 & 15 \\
Density $\left(\mathrm{g} \mathrm{mL}^{-1}\right)$ & 1.034 & 1.026 & 1.023 & - \\
Fat $(\%)$ & 0.3 & 0.4 & 0.3 & 14 \\
Protein $(\%)$ & 3.1 & 1.3 & 1.7 & - \\
TDE $(\%)$ & 8.8 & 6.9 & 6.0 & - \\
NFDE $(\%)$ & 8.6 & 6.5 & 5.9 & - \\
\hline
\end{tabular}

Source: Authors (2021).

According to the RTIQ for UHT Milk (Decree ${ }^{\circ}$ 146, 1996), UHT skim milk, in addition to other requirements, must have an acidity, in $\mathrm{g}$ of lactic acid per $100 \mathrm{~mL}$, from 0.14 to 0.18 (equivalent to 14 to $18^{\circ} \mathrm{D}$ ), a maximum fat content of $0.5 \%$ and a NFDE of at least $8.4 \%$. Brazilian legislation does not establish density, protein and pH standards for UHT milk. Therefore, the standards established for pasteurized skim milk were considered, under Normative Instruction No. 76 (Brazil, 2018), which establishes a density from 1.028 to $1.036 \mathrm{~g} \mathrm{~mL}^{-1}$ and protein of at least $2.9 \%$. According to Tronco (2013), the pH ranges from 6.60 to 6.80 for good quality milk. Thus, based on the average values obtained in the present study (Table 4), the UHT skim milk used was within the established quality standards.

The UHT cream used in this research was classified as "light" in terms of fat content. This cream, in addition to other requirements, must have acidity, in $\mathrm{g}$ of lactic acid per $100 \mathrm{~g}$, of a maximum of 0.20 (equivalent to $20^{\circ} \mathrm{D}$ ) and a fat content from 10.0 to $19.9 \%$, as per Decree no. 146 (Brazil, 1996). Brazilian legislation also does not establish a pH standard for UHT cream. Thus, the result was compared with the $\mathrm{pH}$ values from research carried out by Stephani et al. (2011) on UHT cream sold in Brazil, which ranged from 6.42 to 6.73. Therefore, considering the average results obtained in this research (Table 4), the UHT cream used was within the established quality standards.

For whey and buttermilk, there is still no legislation in Brazil that defines the parameters of identity and quality. The composition of whey can vary according to the type of cheese being manufactured, the heat treatment applied to the milk and the treatment given to the curd, such as cutting and stirring (Abreu \& Gajo, 2012).

Teixeira \& Fonseca (2008) analyzed whey derived from the production of Mussarela and Minas Padrão cheeses from four macroregions in the state of Minas Gerais. The researchers found for the Mozzarella whey the following values: $\mathrm{pH}$ from 5.93 to 6.45 , acidity from 10 to $16^{\circ} \mathrm{D}$, TDE from 5.90 to $6.76 \%$, fat from 0.5 to $1.0 \%$, protein from 0.80 to $0.88 \%$ and density from 1.0257 to $1.0259 \mathrm{~g} \mathrm{~mL}^{-1}$.

The whey used in this research came from the production of Mozzarella cheese and the average pH and acidity values were in accordance with those found by the researchers. Fat, on the other hand, was lower, and density, protein and TDE values were higher than those found by the authors (Table 3 ).

The higher density of whey used in this research is explained by the lower amount of fat, as this component is the one with the lowest density $\left(0.930 \mathrm{~g} \mathrm{~mL}^{-1}\right)$ among the milk constituents. The lower its amount, either in the whey or in the milk, the greater the density of the product tends to be (Tronco, 2013). The TDE was higher due to the greater amount of protein found in the whey used in this study (Table 3 ).

Buttermilk has, on average, 0.4 to $0.5 \%$ fat, $3.5 \%$ protein, 4.6 to $14.5 \%$ TDE, a pH of 4.60 , titratable acidity of $17^{\circ} \mathrm{D}$ and density of $1.034 \mathrm{~g} \mathrm{~mL}^{-1}$ (Walstra et al., 2006; Assumpção \& Paula, 2013; Barukčić et al., 2019). Only the TDE 
found in this research is in agreement with the authors. The difference in values can be explained by the butter production technique, which can greatly vary the buttermilk composition. According to Abreu \& Gajo (2012), many factors can affect the buttermilk composition, such as the percentage of fat in the cream, the physical maturation of the cream, the beating time, the temperature of the cream during the beating, the anticipation of the final beating point and the volume of cream in the mixer.

Another factor that explains the difference in composition found in this research in relation to the aforementioned research is the fact that the cream has been standardized with water, instead of skim milk, modifying the buttermilk composition. As can be seen in Table 4, the buttermilk composition approached the whey composition, and because of this, the protein, TDE, NFDE and density values were lower.

The average results of the physicochemical analyses of the treatments are shown in Table 4.

Table 4. Average results of the physicochemical analyses of the fermented dairy product treatments.

\begin{tabular}{ccccc}
\hline Parameters & T0 & T1 & T2 & T3 \\
\hline pH & $4.26^{\mathrm{a}}$ & $4.30^{\mathrm{a}}$ & $4.29^{\mathrm{a}}$ & $4.28^{\mathrm{a}}$ \\
Acidity $(\%$ of lactic acid) & $0.67^{\mathrm{a}}$ & $0.55^{\mathrm{a}}$ & $0.55^{\mathrm{a}}$ & $0.60^{\mathrm{a}}$ \\
Fat $\left(\mathrm{g} 100 \mathrm{~g} \mathrm{~g}^{-1}\right)$ & $0.5^{\mathrm{a}}$ & $0.4^{\mathrm{a}}$ & $0.3^{\mathrm{b}}$ & $0.3^{\mathrm{b}}$ \\
Protein $\left(\mathrm{g} 100 \mathrm{~g} \mathrm{~g}^{-1}\right)$ & $2.92^{\mathrm{a}}$ & $2.48^{\mathrm{b}}$ & $2.42^{\mathrm{b}}$ & $2.35^{\mathrm{b}}$ \\
Viscosity (cP) & $352.82^{\mathrm{a}}$ & $216.95^{\mathrm{a}}$ & $224.02^{\mathrm{a}}$ & $131.52^{\mathrm{a}}$ \\
$\mathrm{L}^{*}$ & $67.43^{\mathrm{a}}$ & $63.01^{\mathrm{a}}$ & $63.21^{\mathrm{a}}$ & $63.01^{\mathrm{a}}$ \\
$\mathrm{a}^{*}$ & $19.22^{\mathrm{a}}$ & $18.28^{\mathrm{a}}$ & $19.61^{\mathrm{a}}$ & $17.83^{\mathrm{a}}$ \\
$\mathrm{b}^{*}$ & $8.49^{\mathrm{a}}$ & $6.22^{\mathrm{a}}$ & $6.08^{\mathrm{a}}$ & $6.50^{\mathrm{a}}$ \\
\hline
\end{tabular}

The averages followed by the same letter in the lines do not differ from each other by the Scott-Knott test ( $\mathrm{p} \geq 0.05)$. Note: T0 (70\% UHT skim milk and 30\% whey); T1 (70\% buttermilk and 30\% whey); T2 (60\% buttermilk and 40\% whey); T3 (50\% buttermilk and 50\% whey). Source: Authors (2021).

According to the results presented (Table 4), the average values of the $\mathrm{pH}$, acidity, viscosity and color variables $\left(L^{*}, a^{*}, b^{*}\right)$ did not differ at the $5 \%$ level of significance. As for the fat content, there was no significant difference between the average values of $\mathrm{T} 0$ and $\mathrm{T} 1$, nor between $\mathrm{T} 2$ and $\mathrm{T} 3$, but there was a significant difference in the average values of the first two treatments compared to the last two, with the fat levels being higher for $\mathrm{T} 0$ and $\mathrm{T} 1$. For protein, there was no significant difference between the average values of treatments $\mathrm{T} 1, \mathrm{~T} 2$ and $\mathrm{T} 3$. T0, however, had a higher protein content in relation to the other treatments.

The ideal $\mathrm{pH}$ in Fermented Dairy Beverage production ranges from 4.4 to 4.6 and acidity between 60 to $72^{\circ} \mathrm{D}$ (Bahia Technology Network - RETEC / BA, 2007; Minas Gerais Agricultural Research Company - EPAMIG, 2010; Milk Science, 2013). The average $\mathrm{pH}$ values obtained in this research were lower and the acidity of the treatments ranged from 0.55 to $0.67 \%$ lactic acid (equivalent to 55 and $67^{\circ} \mathrm{D}$ ).

The lowest $\mathrm{pH}$ found in this research can be explained by the use of the pineapple and wine mix that has a $\mathrm{pH}$ ranging from 3.0 to 4.0. Acidity is influenced, among other factors, by the time and temperature of fermentation. In this research, the treatments were incubated at $42^{\circ} \mathrm{C}$ for five hours, with no $\mathrm{pH}$ monitoring, to standardize the processing with minimal variations. 
Pfrimer (2018), when developing a Fermented Dairy Beverage with buttermilk and cagaita pulp, obtained $\mathrm{pH}$ values from 3.9 to 4.4, an interval equivalent to the present study (Table 4). Thus, as observed in this research, it was argued that the low $\mathrm{pH}$ value was due to the pulp used.

With regard to acidity, Pfrimer (2018) obtained lactic acid values from 0.36 to $0.58 \%$ while those of this research were from 0.55 to $0.67 \%$ (Table 4). The higher values found in this study can be explained by the incubation time of the base mixture, which was longer than that used by the author, in which she applied a temperature of $43^{\circ} \mathrm{C}$ for about three hours.

The viscosity of the product can be influenced by several factors, such as the heat treatment applied, the $\mathrm{pH}$, the amount of NFDE and TDE, the type of milk yeast used, the use of stabilizers and thickeners, the degree of agitation and the temperature during the breaking of the gel (Abreu \& Gajo, 2012). Pfrimer (2018) obtained a reduction in viscosity as the proportion of milk decreased and the proportion of whey and buttermilk in the formulation increased. In this research, as there was a standardization of the NFDE and fat, there was no change in the viscosity of the product (Table 4).

The average $\mathrm{L}^{*}$ values (brightness) ranged from 63.01 to 67.43 , the average $\mathrm{a}^{*}$ values (hue) ranged from 17.83 to 19.61 and the average $b^{*}$ values (saturation) ranged from 6.08 to 8.49 (Table 4). According to Ramos and Gomide (2017), the parameter $\mathrm{L}^{*}$ varies from 0 (pure black) to 100 (pure white), the $\mathrm{a}^{*}$ values can vary from -120 to +120 , being red (when positive) and green (when negative), and the $b^{*}$ values can also vary in the same range, being yellow (when positive) and blue (when negative). Thus, through the average results obtained in this research and with the aid of the CIELAB system's chromaticity diagram, the product arrived at the pink hue region (Figure 2).

Figure 2. Color of treatments T0, T1, T2 and T3. Note: T0 (70\% UHT skim milk and 30\% whey); T1 (70\% buttermilk and $30 \%$ whey); T2 (60\% buttermilk and 40\% whey); T3 (50\% buttermilk and 50\% whey).

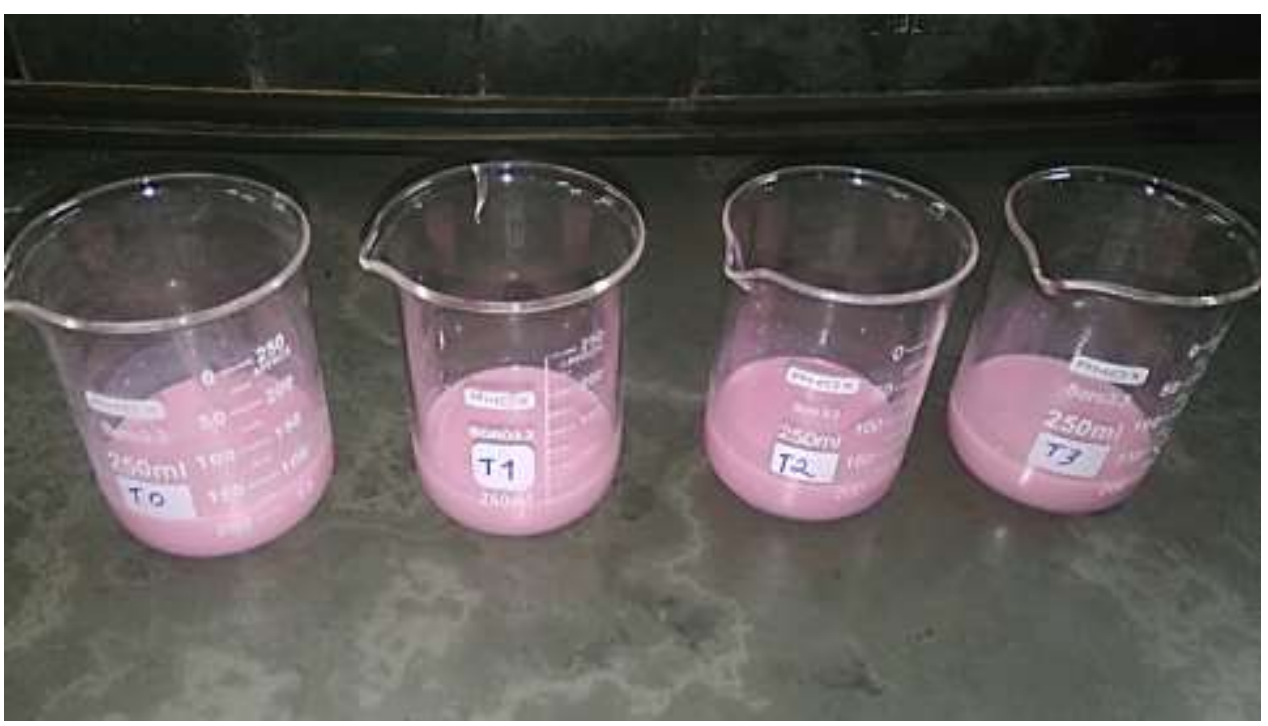

Source: Authors (2021).

Even with the standardization of the base mixture's fat content in this present study, there was a difference in the average fat values between treatments (Table 4). This can be explained due to the fact that after the standardization of the base mixture's fat content, skim milk powder was added for the standardization of the NFDE. The amount of skim milk powder necessary for the standardization of treatments was greater as the proportion of whey increased, and consequently, the fat content of the treatments decreased. 
Pfrimer (2018) obtained higher fat values (1.15 to 2.76\%) when compared to the present study (Table 4). This higher fat proportion was due to the use of whole milk in the formulations. In addition, the proportion of fat used by the author in the mixture (whey and buttermilk) was also higher (ranging from 0.98 to $1.07 \%$ ) than that used in this research (Table 4).

With regard to protein, the average results obtained (Table 4) were compared to the standard established in the RTIQ for Dairy Beverages (Brazil, 2005), which establishes, for Fermented Dairy Beverages with the addition of food

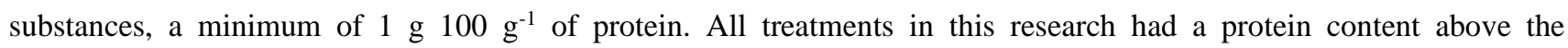
recommended value (Table 4), showing that it is possible to obtain a drink with considerable protein levels without using milk as a raw material.

Treatments that used buttermilk and whey (T1, T2 and T3) had lower average protein contents compared to T0, which used milk and whey. As the protein levels of whey and buttermilk are lower than that of milk, the difference between treatments was to be expected (Table 4). Pfrimer (2018) also obtained a reduction in protein content as the proportion of whey and buttermilk in the product composition increased.

\subsection{Microbiological analyses}

The average results of the microbiological analyses of the treatments were expressed by Colony Forming Units (CFU $\left.\mathrm{g}^{-1}\right)$, as shown in Table 5 .

Table 5. Geometric averages of the microbiological analyses of the fermented dairy product treatments.

\begin{tabular}{ccccc}
\hline Parameters & T0 & T1 & T2 & T3 \\
\hline Lactic Acid Bacteria $\left(\mathrm{CFU} \mathrm{g}^{-1}\right)$ & $9.9 \times 10^{7}$ & $1.4 \times 10^{7}$ & $1.5 \times 10^{7}$ & $1.3 \times 10^{7}$ \\
Total Coliforms $\left(\mathrm{CFU} \mathrm{g}^{-1}\right)$ & $<10$ & $<10$ & $2.7 \times 10^{1}$ & $<10$ \\
E. coli $\left(\mathrm{CFU} \mathrm{g}{ }^{-1}\right)$ & $<10$ & $<10$ & $<10$ & $<10$ \\
\hline
\end{tabular}

Note: T0 (70\% UHT skim milk and 30\% whey); T1 (70\% buttermilk and 30\% whey); T2 (60\% buttermilk and 40\% whey); T3 (50\% buttermilk and 50\% whey). Source: The authors, 2021.

According to the results presented (Table 5), all formulations presented average total coliform counts within the range established by the RTIQ for Fermented Dairy Beverages with addition of food substances (Brazil, 2005), which is a maximum of $100 \mathrm{CFU} \mathrm{g}^{-1}$ for indicative samples (considering the upper limit "M").

The same legislation also establishes that the thermotolerant coliform count must be less than $10 \mathrm{CFU} \mathrm{g}^{-1}$ (Brazil, 2005), also considering the upper limit "M" for indicative samples. In this research, analyses were made for E. Coli, which is a bacterium in the thermotolerant coliform group. In no treatment did E. coli colonies grow (Table 5).

With regard to lactic acid bacteria, the same legislation defines the minimum value as $10^{6} \mathrm{CFU} \mathrm{g}^{-1}$ (Brazil, 2005). All treatments in this research showed average counts above this value (Table 5).

Pfrimer (2018), when developing a Fermented Dairy Beverage with buttermilk and cagaita pulp, also obtained values for lactic acid bacteria and total thermotolerant coliforms within the ranges established by the legislation. Furtado et al. (2020), when counting lactic acid bacteria in fermented strawberry-flavored dairy beverages sold in supermarkets in Vitória da Conquista - Bahia, found only one sample (out of a total of 32) within the standard established by the legislation. 


\subsection{Sensory Analysis}

The average results of the judges' scores regarding flavor, texture, aroma, color, overall impression and purchase intention are shown in Table 6.

Table 6. Average results of the judges 'acceptance in terms of taste, texture, aroma, color, overall impression and purchase intention of the fermented dairy product treatments.

\begin{tabular}{ccccccc}
\hline Treatments & Flavor & Texture & Aroma & Color & $\begin{array}{c}\text { Overall } \\
\text { Impression }\end{array}$ & $\begin{array}{c}\text { Purchase } \\
\text { Intention }\end{array}$ \\
\hline T0 & $8.3^{\mathrm{a}}$ & $8.3^{\mathrm{a}}$ & $8.3^{\mathrm{a}}$ & $8.6^{\mathrm{a}}$ & $8.2^{\mathrm{a}}$ & $5.8^{\mathrm{a}}$ \\
$\mathrm{T} 1$ & $8.1^{\mathrm{a}}$ & $8.3^{\mathrm{a}}$ & $8.2^{\mathrm{a}}$ & $8.5^{\mathrm{a}}$ & $8.2^{\mathrm{a}}$ & $5.5^{\mathrm{a}}$ \\
$\mathrm{T} 2$ & $8.2^{\mathrm{a}}$ & $8.1^{\mathrm{a}}$ & $8.2^{\mathrm{a}}$ & $8.6^{\mathrm{a}}$ & $8.1^{\mathrm{a}}$ & $5.7^{\mathrm{a}}$ \\
$\mathrm{T} 3$ & $8.4^{\mathrm{a}}$ & $8.1^{\mathrm{a}}$ & $8.3^{\mathrm{a}}$ & $8.5^{\mathrm{a}}$ & $8.2^{\mathrm{a}}$ & $5.5^{\mathrm{a}}$ \\
\hline
\end{tabular}

The averages followed by the same letter in the columns do not differ from each other by the Friedman test ( $\mathrm{p} \geq 0.05)$. Note: T0 (70\% skimmed UHT milk and 30\% whey); T1 (70\% buttermilk and 30\% whey); T2 (60\% buttermilk and $40 \%$ whey); T3 (50\% buttermilk and 50\% whey). Source: Authors (2021).

The results showed that there was no significant difference between the average treatment values for flavor, texture, aroma, color and overall impression (at the 5\% level of significance) (Table 6). Thus, the substitution of milk for buttermilk did not affect the acceptance of the judges regarding the aforementioned attributes.

Pfrimer (2018), when developing a Fermented Dairy Beverage with buttermilk and cagaita pulp, did not obtain a significant difference at the $5 \%$ level of significance in the average scores for color and aroma, but obtained a difference in the average scores for flavor, consistency and overall impression, showing a trend in the reduction of the scores with the decrease in the product's proportion of milk. Pfrimer (2018) scored lower than this study: flavor, from 3.3 to 7.5 ; consistency (texture), from 3.5 to 7.7 ; aroma, from 6.1 to 7.6 ; color, from 4.5 to 7.3 and overall impression, from 4.3 to 7.8 .

The average values obtained for flavor, texture, aroma and global impression (Table 6) fit the option "I somewhat liked it". And for the color, the averages meant "I liked it extremely". According to these acceptance results, the product has the potential to be marketed.

Cruz et al. (2020), when preparing fermented milk beverages with different types of fruit pulps (guava, passion fruit, seriguela (Spondias purpurea) and coquinho-azedo (Butia capitata var capitata), obtained greater acceptance in the coquinhoazedo flavored dairy beverage (43.5\%), followed by the passion fruit flavored fermented dairy beverage (38.5\%). There was less acceptance for the guava (32.5\%) and seriguela (12.5\%) flavors. These data show that exotic / different flavors can be rejected by consumers, unlike the pineapple and wine flavor used in this research, as there was great acceptance by the tasters (average score above 8.0 in all analyzed parameters).

As evidenced, there was no significant difference between the average purchase intention values of the treatments at the $5 \%$ level of significance (Table 6). It is also noted that the average purchase intention values obtained in this research are located in the option "I would buy very often". These data suggest that the use of buttermilk is feasible due to purchase potential by consumers. This also holds true for a Fermented Dairy Beverage produced with traditional ingredients (milk and whey).

Pfrimer (2018) obtained a significant difference at the 5\% level of significance in the average scores for purchase intention. As the proportion of milk decreased and the whey and buttermilk in the product increased, there was a tendency for the scores to reduce, which was not evidenced in this research (Table 6). The author obtained scores ranging from 2.0 to 4.2 for the purchase intention, being lower than those obtained in this research. 
The overall data obtained in this research, in relation to physicochemical, microbiological and sensory analyses, demonstrated that it is possible to transform a by-product usually destined for disposal, as is the case of buttermilk, into a product with greater added value. The pineapple and wine flavor was well accepted by the judges, showing it to be an alternative flavor for the production of fermented dairy products.

Based on the results presented in this research, on April 1, 2021, a patent application for the invention of a product and process entitled "Fermented Dairy Product Based on Whey and Buttermilk and Obtaining Process" was filed with the National Institute of Industrial Property (INPI) under protocol No. 870210030619, with the processing number nº BR 1020210063912.

\section{Conclusion}

The developed product presented satisfactory physicochemical and microbiological results and was in accordance with the legislation requirements. With regard to sensory analysis, the addition of buttermilk as a substitute for milk did not affect the acceptance of the judges with respect to taste, texture, aroma, color, overall impression and purchase intention.

This research has shown that it is possible to produce a fermented dairy product based on whey and buttermilk with potential for insertion in the market as a new product.

Further studies are suggested on the production of fermented dairy products based on whey and buttermilk as there are few published studies on the subject.

\section{References}

3M do Brasil. (2009). Guia de interpretação: placas $3 M^{\mathrm{TM}}$ Petrifilm ${ }^{\mathrm{TM}}$ para contagem de E. coli e Coliformes. Sumaré.

Alves, M. P., Moreira, R. de O., Júnior, P. H. R., Martins, M. C. de F., Perrone, Í. T., \& Carvalho, A. F. de. (2014). Soro de leite: tecnologias para o processamento de coprodutos. Revista do Instituto de Laticínios Cândido Tostes, 69(3), 212-226. https://www.revistadoilct.com.br/rilct/article/view/341.

Abreu, L. R. de \& Gajo, A. A. (2012). Tecnologia de produtos lácteos. Lavras: UFLA/FAEPE.

Assumção, G. M. P. \& Paula, A. A. A. de. (2013). Utilização do leitelho na fabricação da ricota em substituição ao leite desnatado. RETEC - Revista de Tecnologias, Ourinhos, v. 6, n. 2, p. 17-30. https://www.fatecourinhos.edu.br/retec/index.php/retec/article/view/38.

Barukčić, I., Jakopović, K. L., \& Božanić, R. (2019). Valorisation of whey and buttermilk for production of functional beverages-an overview of current possibilities. Food technology and biotechnology, 57(4), 448-460. https://hrcak.srce.hr/index.php?show=clanak\&id_clanak_jezik=339470.

Bento, R. de A., Andrade, S. A. C. \& Silva, A. M. A. D. (2013). Análise sensorial de alimentos. Recife: Universidade Federal Rural de Pernambuco.

Brasil. Ministério da Agricultura, Pecuária e Abastecimento. Instrução Normativa ${ }^{\circ} 16$ de 23 de agosto de 2005. Aprova o regulamento técnico de identidade e qualidade de bebida láctea. Diário Oficial da União, Brasília, DF, 24 ago. 2005.

Brasil. Ministério da Agricultura, Pecuária e Abastecimento. Instrução Normativa n 68 de 12 de dezembro de 2006 . Oficializa os métodos analíticos oficiais físico-químicos, para controle de leite e produtos lácteos. Diário Oficial da União, Brasília, DF, 14 dez. 2006.

Brasil. Ministério da Agricultura, Pecuária e Abastecimento. Instrução Normativa n 76 de 26 de novembro de 2018 . Aprova os regulamentos técnicos de identidade e qualidade do leite cru refrigerado, do leite pasteurizado e do leite pasteurizado tipo A. Diário Oficial da União, Brasília, DF, 30 nov. 2018.

Brasil. Ministério da Agricultura, Pecuária e Abastecimento. Portaria n 146 de 07 de março de 1996. Aprova os regulamentos técnicos de identidade e qualidade dos produtos lácteos. Diário Oficial da União, Brasília, DF, 11 mar. 1996.

Brookfield. (2015). Operating instructions: manual $n^{\circ}$. M03-165-F0612. Middleboro.

Ciência do Leite. (2013). Estabilização de iogurte e bebida láctea fermentada. Retrieved April 12, 2021, from https://cienciadoleite.com.br/noticia/3166/estabilizacao-de-iogurte-e-bebida-lactea-fermentada.

Cruz, G. P. da, Rocha, F. R. dos S., Assis, K. B. O. de, Palma, A. B. O., Durães, R. R., Sales, M. S. M., Araújo, M. F., Silva, D. M. da, Oliveira, J. A. N. \& Farias, P. K. S. (2020). Elaboração de bebida láctea fermentada com diferentes tipos de polpas de frutas. Caderno de Ciências Agrárias, 12, 1-6. https://periodicos.ufmg.br/index.php/ccaufmg/article/view/18137.

Embrapa Gado de Leite. (2018). Anuário leite 2018: indicadores, tendências e oportunidades para quem vive no setor leiteiro. https://www.embrapa.br/buscade-publicacoes/-/publicacao/1094149/anuario-leite-2018-indicadores-tendencias-e-oportunidades-para-quem-vive-no-setor-leiteiro. 
Furtado, L. F. L., Gonçalves, I. A. T., Lima, C. M. G., Pagnossa, J. P., Figueiredo, R. M. de, Medeiros, U. B. C., \& Barbosa, A. A. (2020). Contagem de bactérias probióticas em bebida láctea fermentada sabor morango. Research, Society and Development, v. 9, n. $7, \quad$ p. e74973696. https://www.researchgate.net/profile/Clara-Goncalves-Lima/publication/341001641_Probiotic_bacteria_counting_in_strawberry-

flavored_fermented_milk_beverage/links/5ebd307b458515626ca80bde/Probiotic-bacteria-counting-in-strawberry-flavored-fermented-milk-beverage.pdf

Instituto Brasileiro de Geografia e Estatística. (2021). Tabela 1086 - número de informantes e quantidade de leite cru, resfriado ou não, adquirido e industrializado, no mês e no trimestre, por tipo de inspeção. Retrieved April 15, 2021, from https://sidra.ibge.gov.br/tabela/1086.

Instituto Brasileiro de Geografia e Estatística. (2021). Tabela 6705 - Produção e vendas dos produtos elou serviços industriais, segundo as classes de atividades e os produtos. Retrieved April 15, 2021, from https://sidra.ibge.gov.br/acervo\#/S/Q

Instituto Adolfo Lutz. (2008). Métodos físico-químicos para análise de alimentos. São Paulo: Instituto Adolfo Lutz.

Konica Minolta. (2013). Manual de instrucciones: Chroma Meter CR-400/410.

Oliveira, D. F. de, Bravo, C. E. C. \& Tonial, I. B. (2012). Soro de leite: um subproduto valioso. Revista do Instituto de Laticínios Cândido Tostes, Juiz de Fora, v. 67, n. 385, p. 64-71. Retrieved April 16, 2021, from https://www.revistadoilct.com.br/rilct/article/view/215.

Organização das Nações Unidas para Agricultura e Alimentação. (2021). FAOSTAT - Statistics Division. http://www.fao.org/faostat/en/\#home.

Pereira, A. S., Shitsuka, D. M., Parreira, F. J., \& Shitsuka, R. (2018). Metodologia da pesquisa científica. Santa Maria: UAB/NTE/UFSM. Retrieved June 06, 2021, from, de https://repositorio.ufsm.br/bitstream/handle/1/15824/Lic_Computacao_Metodologia-Pesquisa-Cientifica.pdf?sequence=1.

Pfrimer, R. T. (2018). Desenvolvimento e avaliação de bebida láctea fermentada acrescida de leitelho e saborizada com polpa de cagaita (Eugenia dysenterica). Dissertação de Mestrado em Ciência Animal, Universidade Federal de Goiás, Cidade de Goiás, GO, Brasil.

Ramos, E. M. \& Gomide, L. A. de M. (2017). Avaliação da qualidade de carnes: fundamentos e metodologias. Viçosa, MG: Ed. UFV.

Rede de Tecnologia do Rio de Janeiro. (2006). Dossiê técnico: produção de polpa de fruta congelada e suco de frutas. Rio de Janeiro.

Rede de Tecnologia da Bahia. (2007). Dossiê técnico: ricota e bebida láctea. Bahia.

Serviço Brasileiro de Apoio às Micro e Pequenas Empresas. (2018). O que quer o consumidor da indústria de alimentos e bebidas? Retrieved April 14, 2021, from https://sebraers.com.br/alimento/o-que-quer-o-consumidor-da-industria-de-alimentos-e-bebidas/.

Silva, N. da, Junqueira, V. C. A., Silveira, N. F. de A., Taniwaki, M. H., Gomes, R. A. R. \& Okazaki, M. M. (2007). Manual de métodos de análise microbiológica de alimentos. 3. ed. São Paulo: Varela.

Souza, C. F. de \& Hemkemeier, M. (2020). Pós tratamento por eletrocoagulação de efluente do processamento do soro de leite tratado por reator anaeróbio. Research, Society and Development, v. 9, n. 9, p. e623997509-. Retrieved April 14, 2021, from https://rsdjournal.org/index.php/rsd/article/view/7509.

Stephani, R., Neves, H de C., Neves, E. O., Souza, A. B. de, Perrone, Í. T., \& Silva, P. H. F. da (2011). Caracterização físico-química do creme de leite UHT comercializado no Brasil. Revista do Instituto de Laticínios Cândido Tostes, 66(379), 25-29. https://www.revistadoilct.com.br/rilct/article/view/158.

Teixeira, L. V. \& Fonseca, L. M. (2008). Perfil físico-químico do soro de queijos mozarela e minas-padrão produzidos em várias regiões do estado de minas gerais. Arquivo Brasileiro de Medicina Veterinária e Zootecnia, Belo Horizonte, v. 60, n. 1, p. 243-250. https://www.scielo.br/scielo.php?pid=S0102$09352008000100033 \&$ script=sci_abstract\&tlng=es.

Tronco, V. M. (2013). Manual para inspeção da qualidade do leite. Santa Maria: Ed. UFSM.

Valente, G. D. F. S., Gaspardi, A. L. A. \& Oliveira, L. D. A. (2015). Utilização do experimento de misturas de vértices extremos para avaliação de doce de leite com soro de leite. Revista do Instituto de Laticínios Cândido Tostes, Juiz de Fora, v. 70, n. 1, p. 01-08. https://revistadoilct.com.br/rilct/article/view/354.

Vanderghem, C., Bodson, P., Danthine, S., Paquot, M., Deroanne, C., \& Blecker, C. (2010). Milk fat globule membrane and buttermilks: from composition to valorization. Biotechnology, Agronomy, Society and Environment, Gembloux, v. 14, n. 3, p. 485-500. https://popups.uliege.be/1780-4507/index.php?id=5828.

Walstra, P., Wouters, J. T. M. \& Geurts, T. J. (2006). Dairy science and technology. 2 ed. Boca Raton: Taylor \& Francis Group.

Wille, G. M. F., Wille, S. A. D. C., Koehler, H. S., Freitas, R. J. S. de, \& Haracemiv, S. M. C. (2004). Práticas de desenvolvimento de novos produtos alimentícios na indústria paranaense. Revista FAE, Curitiba, v. 7, n. 2, p. 33-46. https://revistafae.fae.edu/revistafae/article/view/418. 